\title{
BERDONO SINDROMO (DIDELĖS ŠLAPIMO PŪSLE்S - MAŽOS GAUBTINĖS ŽARNOS - SUMAŽĖJUSIOS ŽARNŲ PERISTALTIKOS SINDROMO) KLINIKINIS ATVEJIS
}

\author{
Agnė Čibirkaite்1, Paulina Tekoriute் ${ }^{1}$, Evelina Bučionyte் ${ }^{1}$, Rūta Rokaite் \\ ${ }^{1}$ Lietuvos sveikatos mokslu universiteto Medicinos fakultetas, \\ ${ }^{2}$ Lietuvos sveikatos mokslu universiteto Medicinos akademija, Vaiku ligu klinika
}

\begin{abstract}
Raktažodžiai: didelès šlapimo pūslès - mažos gaubtinès žarnos - sumažejjusios žarnų peristaltikos sindromas, Berdono sindromas, vidurių užkietėjimas, dinaminis žarnyno nepraeinamumas.
\end{abstract}

\begin{abstract}
Santrauka
Berdono sindromas arba didelès šlapimo pūslès - mažos gaubtinès žarnos - sumažejusios žarnų peristaltikos sindromas (angl. megacystis microcolon intestinal hypoperistalsis syndrome (MMIHS)) yra labai retas, igimtas ir gyvybei pavojingas sindromas, kurio tikslus paplitimas nèra žinomas. Šiame straipsnyje pristatomas Berdono sindromo klinikinis atvejis. Šio sindromo metu pasireiškia pasikartojantys dinaminio žarnyno nepraeinamumo simptomai bei šlapimo pūslès tonuso sutrikimai, sukeliantys šlapimo susilaikymą, nesant jokios distalinès obstrukcijos, kliudančios nutekèti šlapimui. Mūsų aprašomam pacientui šis sindromas buvo patvirtintas molekuliniais genetiniais metodais Japonijos Keio universitete, nustačius de novo atsiradusi ACTG2 geno c. 769C $>$ T, pArg257Cys heterozigotini patogenini variantą. Berdono sindromas gydomas tik simptomiškai taikoma parenterinè mityba bei didelès šlapimo pūslès kateterizavimas.
\end{abstract}

\section{Ivadas}

Didelès šlapimo pūslès - mažos gaubtinès žarnos - sumažèjusios žarnų peristaltikos sindromas, dar žinomas kaip Berdono sindromas, yra labai retas, igimtas sutrikimas, apibūdinamas funkcine šlapimo sistemos organų bei virškinamojo kanalo pseudoobstrukcija [1]. Pirmą kartą šią būklę 1976 metais aprašè V. Berdonas su kolegomis. Mokslinèje literatūroje per 42 metus (1976-2018 m.) buvo aprašyta tik 450 pacientų, kuriems diagnozuotas šis sindromas [2]. Berdono sindromas daro didelę neigiamą įtaką gyvenimo kokybei, kadangi pacientams dažnai prireikia visą gyvenimą taikyti parenterinį maitinimą bei nuolatines, protarpines šlapimo pūslès kateterizacijas [3]. Chirurginès intervencijos ir bandymai pagerinti šlapimo ir virškinimo sistemos organų funkciją dažniausiai būna nesèkmingi, todèl šis sutrikimas būna mirtinas [6]. Pacientai dažniausiai miršta pasireiškus ryškiam virškinimo ir šlapimo sistemos organų nepakankamumui, progresuojant malabsorbcijos sindromui, nusilpus imunitetui ir prisidejus infekcinei ligai su sepsiu. Šio sindromo atveju vienintelè viltis galètų būti dauginè organų transplantacija $[4,5]$.

Darbo tikslas - supažindinti ịvairių specialybiu gydytojus su itin retai pasitaikančio Berdono sindromo klinikiniu atveju.

\section{Klinikinis atvejis}

Prenataliniu laikotarpiu, nuo 30 néštumo savaitès, vaisiui buvo stebėta didelè šlapimo pūslè (1 pav.). Berniukas gimé 39 sav. gestacinio amžiaus, $3648 \mathrm{~g}$ svorio, $53 \mathrm{~cm}$ ūgio, 35 $\mathrm{cm}$ galvutès bei $33 \mathrm{~cm}$ krūtinès apimties. Po gimimo pagal Apgar skalę įvertintas 7-7 balais. 24 val. amžiaus naujagimiui buvo atlikta apžvalginè pilvo organų rentgenograma (2 pav.), pilvo organų kompiuterinès tomografijos tyrimas, kuriame buvo matomas dešinejje pilvo pusèje, nuo pat apatinio kepenų krašto iki dubens šlapimo pūslès projekcijos 10,5 x 7,8 x 6,4 $\mathrm{cm}$ dydžio cistinis darinys $(18 \mathrm{ml}$ tūrio, su $0,2 \mathrm{~cm}$ storio sienele), ne visai skaidriu, tačiau homogenišku turiniu. Itvedus šlapimo pūslès kateterị, cistinis darinys išnyko, todèl buvo nuspręsta, kad tai yra prisipildžiusi šlapimo pūslè. Atlikus cistogramą ir cistoskopiją, nustatyta ịgimta, didele šlapimo pūslè (megacystis congenita).

Vaikui augant, dažnai kartojosi šlapimo takų infekcijos: 5 mèn. - cistito, 6 mèn. bei $1 \mathrm{~m}$. amžiaus - ūminio pielonefrito epizodai. Nuo 1,5 metų berniukui pradèta pastoviai kateterizuoti šlapimo pūslę, atsiradus šlapimo susilaikymui. Nuolat kateterizuojant šlapimo pūslę bei taikant profilaktinị gydymą nitrofurantoinu, šlapimo takų infekcijos kartojosi retai. 
Nuo pat gimimo pacientas tuštinosi retai, kietokomis išmatomis, todèl pastoviai vartojo vidurių laisvinamuosius preparatus. 8 mèn. amžiaus pacientui atlikus ultragarsinę irigoskopiją bei retrogradinị rentgenokontrastinị žarnyno tyrimą, nustatyta, kad lètinio vidurių užkietejimo priežastis yra storosios žarnos funkciniai sutrikimai.

Pirmą kartą dinaminio žarnyno nepraeinamumo klinika (neramumas, vėmimas, išpūstas pilvas, dujų bei išmatų susilaikymas) išryškejjo 10 mènesių amžiaus. Toliau kartojosi žarnyno nepraeinamumo epizodai, nesant mechaninès priežasties: 1 metų ir 9 mèn. (taikytas konservatyvus gydymas klizmomis) bei 2 metų ir 3 mẻn. amžiaus, kai atlikus apžvalginę pilvo rentgenogramą, buvo stebetos labai išpūstos žarnų kilpos (3 pav.). İtarus žarnų apsisukimą, buvo atlikta skubi laparotomija, tačiau mechaninè žarnyno nepraeinamumo priežastis nepasitvirtino.

Po 2 savaičių vèl išryškejjus žarnų nepraeinamumo klinikai, atlikta pakartotinè laparotomija, kurios metu rastos tamprios tarpžarninès sąaugos, tarp kurių ịlindusi ir užsisu-
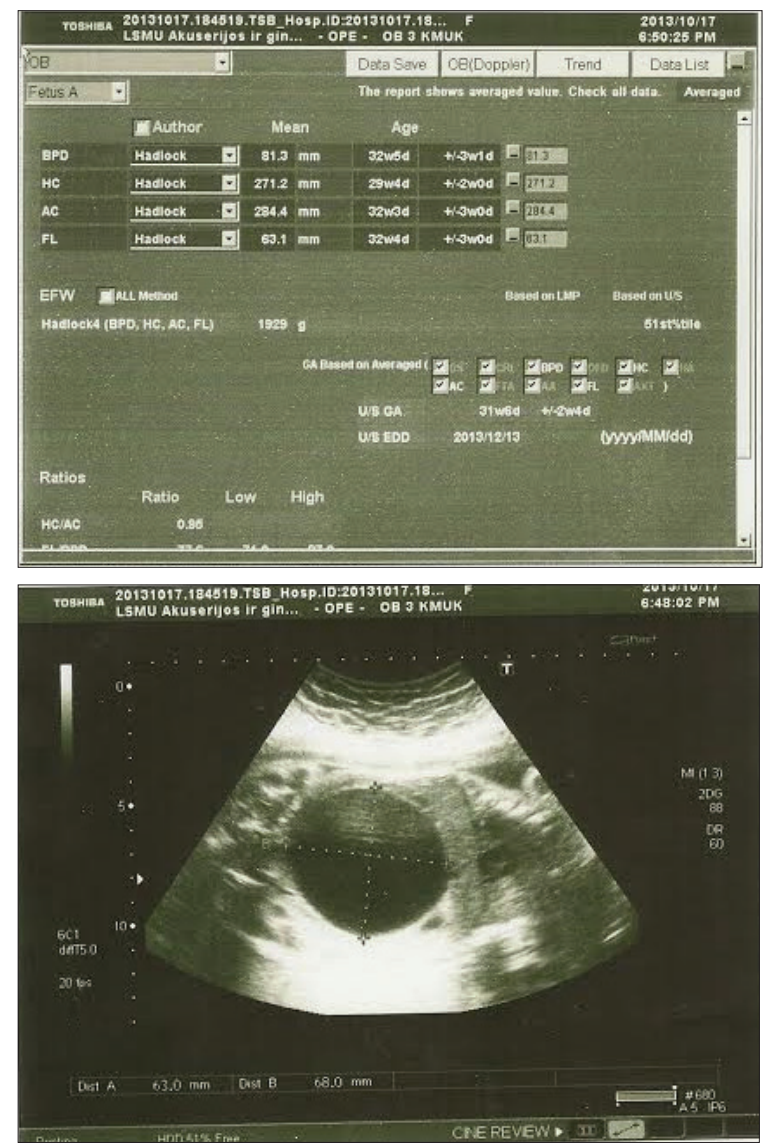

1 pav. Vaisiaus (30 nėštumo sav.) ultragarso tyrimas: didelè šlapimo pūslè kusi plonosios žarnos kilpa. Sąaugos buvo atidalintos, žarnos kilpa atsukta be nekrozès požymių. Operacijos metu suformuota kolostoma bei paimtos biopsijos iš storosios žarnos. Pathistologiniame biopsiniu preparatų tyrime rasta storosios žarnos nervinių pluoštų hiperplazija ir hipertrofija, morfologinis vaizdas būdingas intestinaliniam ganglioneuromatozès difuziniam tipui. Pacientui, stebint mitybos nepakankamumą (svoris $<3$ procentilio), vietoj ịprastinio maisto rekomenduojama maitintis geriamaisiais specialiosios medicininès paskirties maisto produktais, skirtais tokio amžiaus vaikams, taip pat tęsti šlapimo pūslès kateterizacijas (3-4 kartus per

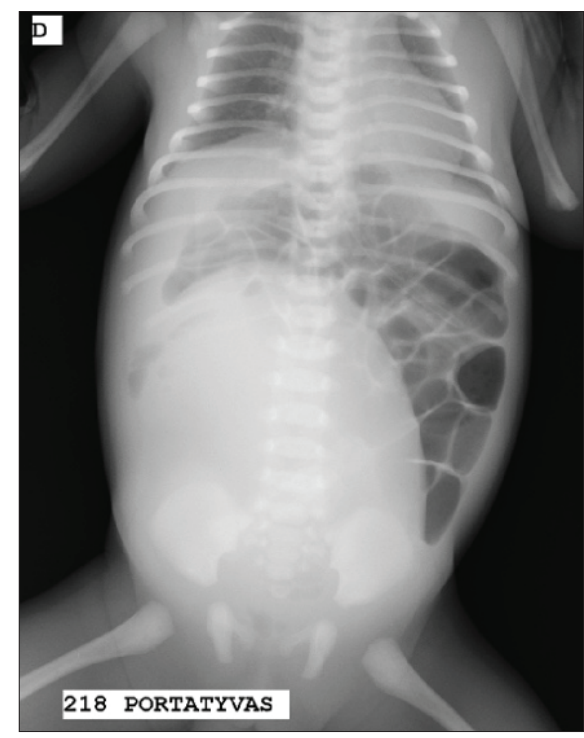

2 pav. Apžvalginė pilvo rentgenograma, 24 val. po gimimo

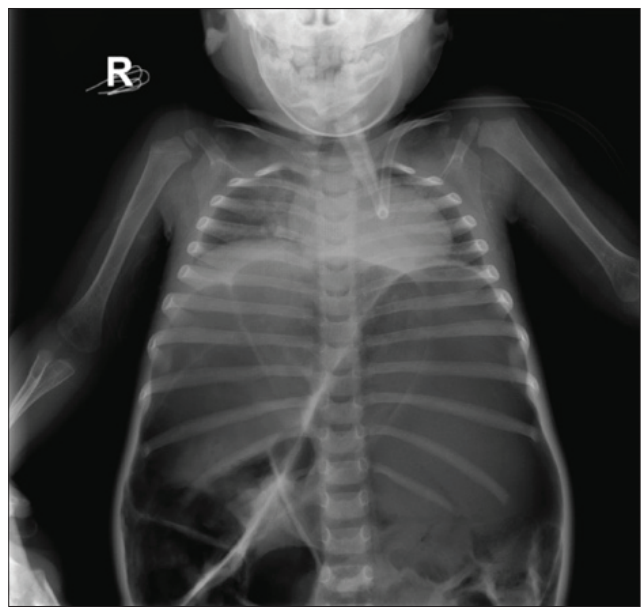

3 pav. Apžvalginė pilvo rentgenograma: išpūstos žarnų kilpos 
dieną) bei klizmavimus per suformuotą kolostomą (2 kartus per dieną).

Praejjus kelioms savaitėms, 2,5 metų pacientas pakartotinai operuotas dèl įstrigusios kolostomos. Evaginavusios ir įstrigusios kolostomos nepavyko sẻkmingai reponuoti ir susiaurinti kolostomos angos kisetine siūle, todèl buvo atlikta rekonstrukcinè žarnyno operacija - kairiosios pusès hemikolektomija, skersinès storosios žarnos dalies jungtis su tiesiaja žarna ir suformuota Santuli tipo ileostoma (4 pav.).

Pacientui sulaukus 3 metų, dèl ryškèjančios stazès skrandyje, ypač vakarais, buvo suformuota gastrostoma (stazinio turinio pašalinimui). Dèl ryškèjančio mitybos nepakankamumo skirtas parenterinis maitinimas nakties metu (12 val.) per centrinès venos kateterị Broviac, tęstas geriamujų specialiosios medicininès paskirties maisto produktų vartojimas (5 pav.).

Skiriant specialiosios medicininès paskirties maisto produktus per burną bei parenterinį maitinimą nakties metu, pradejjo augti paciento svoris, išnyko mitybos nepakankamumas, nesikartojo žarnyno nepraeinamumo klinika, nors kas vakarą per gastrostomą buvo išleidžiama apie 200-300 $\mathrm{ml}$ skrandyje esančio turinio. Pacientas nesituštino, todèl 2 kartus per savaitę buvo atliekamos valomosios klizmos.

Sulaukus 5 metų, paciento būklè pablogèjo - pradejjo didèti stazè skrandyje, valomosiomis klizmomis nepavyko iš organizmo pašalinti išmatų sankaupų, atsisakè vartoti specialiosios paskirties maisto produktus, todèl buvo maitinamas tik parenteriniu būdu. Dèl didèjančios stazès skrandyje (viršutinès endoskopijos metu buvo matomas suspaustas skrandis, nepraeinama, spaudžiama iš išorès, dvylikapirštės žarna) atlikta dešinioji hemikolektomija ir plonosios žarnos klubinè dalis sujungta su tiesiaja žarna.

Stebèti dismorfiniai paciento bruožai: žemokai ausys, hipertelorizmas, abipusis epikantas, mažas apatinis žandikaulis, kojų II ir III pirštų sindaktilija, tačiau atliktame genetiniame tyrime jokių pakitimų nebuvo rasta. Tik berniukui sulaukus 4 metų, moksliniais tikslais atliktas egzomo tyrimas Japonijos Keio universitete nustate de novo atsiradusi ACTG2 geno c. $769 \mathrm{C}>\mathrm{T}$, pArg257Cys heterozigotini patogenini variantą, patvirtinantį didelès šlapimo pūslès - mažos gaubtinès žarnos - sumažèjusios žarnų peristaltikos sindromą (angl. megacystis microcolon intestinal hypoperistalsis syndrome (MMIHS)) arba Berdono sindromą. Šiam sindromui nèra etiologinio gydymo, todèl pacientui skirtas simptominis gydymas, dalyvaujant daugiadisciplininei specialistų komandai. Pastaruoju metu berniukui skirtas pilnas parenterinis maitinimas bei šlapimo pūslès kateterizacijos. Taikant simptomini gydymą, paciento svoris bei ūgis dideja amžiaus normos ribose (6 pav.), žarnyno nepraeinamumo klinika nesikartoja, laboratoriniai tyrimai atitinka normas.

\section{Diskusija}

Berdono sindromas yra labai reta (tikslus paplitimas nèra žinomas), igimta ir dažnai mirtimi pasibaigianti naujagimių dinaminio žarnyno nepraeinamumo priežastis [2]. Visai neseniai molekuliniais genetiniais tyrimais nustatyti pagrindiniai genai, susiję su šiuo sindromu: ACTG2 (angl. actin gamma 2), MYH11 (angl. myosin heavy chain 11), LMOD1 (angl. leiomodin 1), MYLK (angl. myosin light chain (MLC) kinase) [1]. Nakamura H. su bendraautoriais, atlikę sisteminę literatūros apžvalgą (išanalizavo 1976-2018 metais išleistus straipsnius, kuriuose aprašyti šeiminio didelès šlapimo pūslès - mažos gaubtinès žarnos -sumažejjusios žarnų peristaltikos sindromo atvejai), pastebejo tos pačios šeimos narių genetini polinkį sindromui. Atrinktose 25 daugiavaikèse šeimose augo Berdono sindromu sergantys vaikai. Iš jų 22 šeimose buvo du sergantys vaikai, o 3 šeimos augino po 3 Berdono sindromu sergančius vaikus. Toks ligos pasikartojimas tarp palikuonių, esant sveikiems tèvams, leidžia įtarti, kad Berdono sindromas yra autosominiu recesyviniu būdu paveldimas sutrikimas [2]. Kitame tyrime, kuriame buvo nagrinèjami ACTG2 geno mutacijos sukelti létinès žarnyno pseudoobstrukcijos atvejai, pabrèžiama, kad Berdono sindromas, sukeltas ACTG2 geno mutacijos, paveldimas autosominiu dominantiniu būdu [4], tad reikia turèti omeny, kad ši sindromą gali sukelti ịvairių genų mutacijos ir jis gali būti tiek pirmasis atvejis šeimoje (de novo mutacija, kurios tėvų genomuose nèra), paveldi-

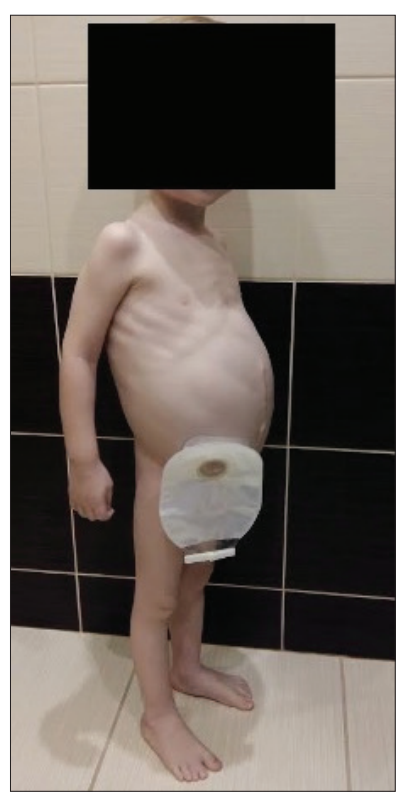

4 pav. Išsipūtęs pilvas, ileostoma

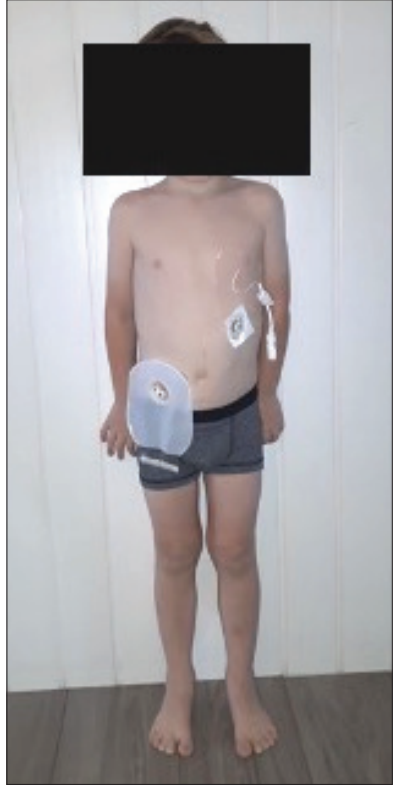

5 pav. Pacientas 5 metų. Suformuota ileostoma, gastrostoma bei centrinès venos kateteris Broviac 
mas autosominiu recesyviniu (ypač kai sveiki tèvai augina kelis sergančius vaikus) ar autosominiu dominantiniu būdu. Šiame klinikiniame atvejyje nagrinejjamam pacientui nustatytas autosominiu dominantiniu būdu paveldimas ACTG2 geno, koduojančio lygiujų raumenų baltymą, heterozigotinis patogeninis variantas. Nei vienas iš paciento tèvų neserga, todèl mutacijos jie neturi ir šis patogenetinis geno variantas atsirado de novo.

Lygiojo raumens susitraukimas yra sudètingų molekulinių procesų, kurių metu vyksta plonų aktino ir storų miozino filamentų sąveika, rezultatas. Bet kurio baltymo netekimas daro neigiamą įtaką ląstelių fiziologijai ir sutrikdo raumens susitraukimą. Esant ACTG2 geno pokyčiui, sutrinka lygiujų raumenų vystymasis. Šie raumenys sudaro žarnyno, šlapimo pūslès sienelę, todèl sutrinka šių organų peristaltika ir funkcija. Simptomus Berdono sindromo metu gali sukelti sutrikusi žarnyno nervinių mazgų ląstelių funkcija $[7,8]$. Nagrinėjamu atveju, pacientui nustatyta ACTG2 geno mutacija, o šio geno koduojamas baltymas svarbus normaliai aktino funkcijai. Šiam pacientui atliktame storosios žarnos

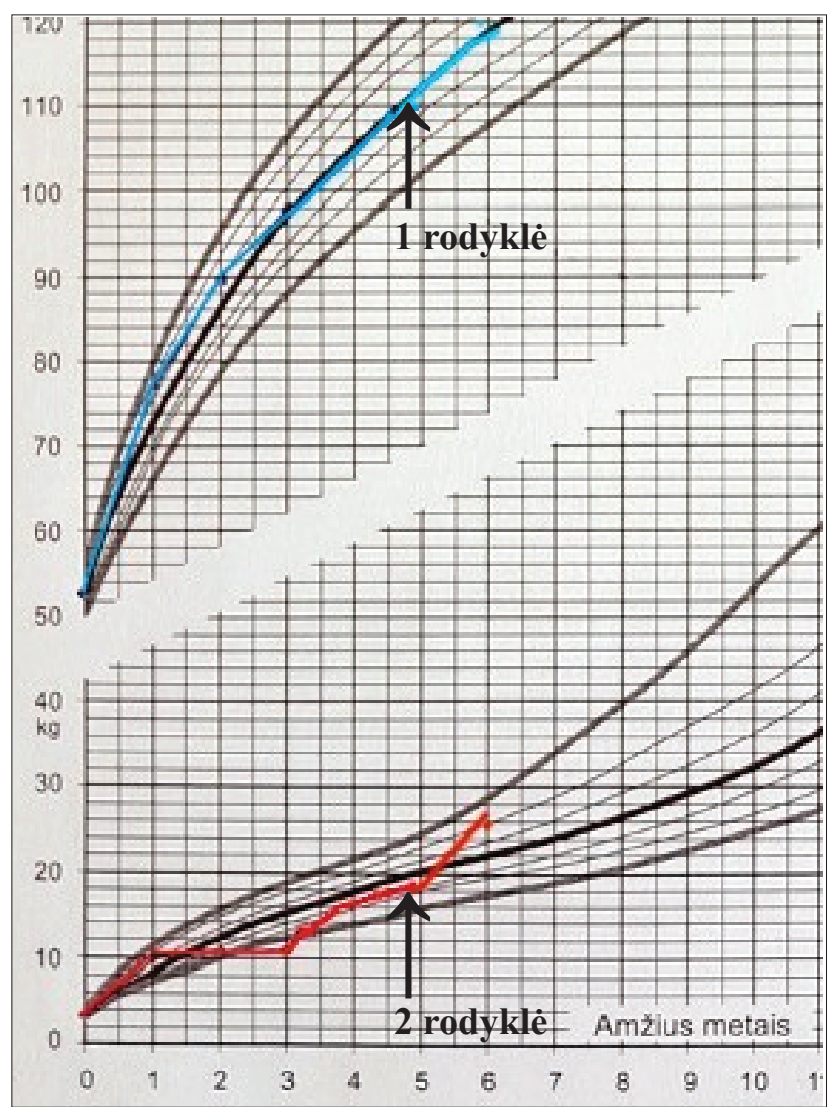

6 pav. Ūgio (1 rodyklè) bei svorio (2 rodyklè) didèjimas nuo gimimo iki 6 metų sienelės histologiniame tyrime nustatyta nervinių pluoštų hiperplazija ir hipertrofija, todèl virškinimo sistemos funkcija buvo nevisavertè tiek dèl inervacijos sutrikimų, tiek dèl lygiesiems raumenims svarbaus baltymo trūkumo.

Berdono sindromui būdingi nuolat pasikartojantys žarnyno obstrukcijos požymiai, nesant mechaninès nepraeinamumo priežasties. Kartu pasireiškia šlapimo pūslès tonuso sutrikimai, manifestuojantys šlapimo susilaikymu nesant jokios distalinès obstrukcijos, kuri kliudytų nutekèti šlapimui [8]. Nagrinèjamuoju atveju pacientui dar naujagimystès laikotarpiu buvo padidejusi pilvo apimtis, jis nesugebejo savaime šlapintis ir tuštintis.

Berdono sindromo gydymas yra tik simptominis. Dažniausiai atliekamos chirurginès intervencijos, skiriami prokinetiniai medikamentai, antibiotikai (esant infekcijų), užtikrinama mityba [8]. Šiuo atveju taikomas simptominis gydymas, pacientas nuolat konsultuojamas ịvairių specialybių gydytojų (urologo, gastroenterologo, dietologo, chirurgo), užtikrinama tinkama slauga - savalaikẻ šlapimo pūslès kateterizacija, infekcijų profilaktika, skirtas enterinis ir parenterinis maitinimas, vèliau tik parenterinis maitinimas ir kt. Pacientui pašalinta storoji žarna (likusi tik tiesioji žarna), suformuota ileostoma bei gastrostoma (stazinio turinio pašalinimui).

Berdono sindromo prognozė yra bloga. A. Milunsky su bendraautoriais, išanalizavę 111 pacientų, kuriems pasireiške lėtinè žarnyno pseudoobstrukcija su ar be ịgimtos didelès šlapimo pūslès, nustatė 49 (44,1 proc.) pacientams ACTG2 geno mutaciją. Tyrèjams pakartotinai (praejjus 15 ar daugiau metų) susisiekus su 7 pacientų, kuriems buvo nustatyta ACTG2 geno mutacija, šeimomis, išsiaiškinta, kad 6 pacientams prireikè nuolatinès, protarpinès šlapimo pūslès kateterizacijos, 4 reikejo pilno parenterinio maitinimo, 3 buvo atlikta kolektomija bei suformuota gastrostoma ir ileostoma, o 3 buvo mirę (atitinkamai 6 mèn., 2 bei 11,5 metų). Vienai 38 metų pacientei buvo atlikta dauginè organų transplantacija (skrandžio, žarnyno, kepenų, kasos, tulžies pūslès ir blužnies) [4]. Mūsų pacientui atlikta kolektomija, suformuota ileostoma bei gastrostoma, taikomas parenterinis maitinimas, atliekamos nuolatinès, protarpinès šlapimo pūslẻs kateterizacijos. Po chirurginių intervencijų mūsų pacientui nesikartoja dinaminio žarnyno nepraeinamumo epizodai, pagerejjo bendroji būklè. Kartu taikant enterinị ir parenterinị maitinimą, o vẻliau tik pilną parenterinị maitinimą, paciento psichomotorinis ir fizinis isšivystymas atitinka amžiaus normas, tačiau kartojasi šlapimo takų infekcijos. Vis dèlto, vaiko žarnyno funkcija negereja, vienintelis potencialus ligos gydymas yra dauginė organų transplantacija, persodinant skrandi, žarnyną, kepenis, tulžies pūslę, kasą bei blužnį.

Berdono sindromas yra nepaprastai reta ir grèsminga 
būklè. Nors šis sindromas neturi etiologinio gydymo ir jo nustatymas nepakeičia daugiadisciplinès paciento priežiūros taktikos, jo diagnostika suteikia aiškumo tiek tèvams, tiek gydytojams, igalina genetinį kitų šeimos narių konsultavimą dèl patologijos pasikartojimo palikuonims. Būtent todèl pasirinkome aprašyti šį nedažną, tačiau ryškiai gyvenimo kokybę bloginantị sindromą.

\section{Išvados}

1. Apie Berdono sindromą reikia pagalvoti, kai pacientas gimsta su igimta didele šlapimo pūsle ir kartojasi žarnyno nepraeinamumo epizodai, nesant mechaninès priežasties.

2. Didelès šlapimo pūslès - mažos gaubtinès žarnos sumažejusios žarnų peristaltikos sindromas paveldimas tiek autosominiu recesyviniu, tiek autosominiu dominantiniu būdu ir diagnozuojamas atlikus molekulinius genetinius tyrimus bei nustačius būdingus pakitimus genuose.

3. Berdono sindromo gydymas simptominis, o prognozé - bloga.

4. Prižiūrèti Berdono sindromu sergančius pacientus reikalinga daugiadisciplininè gydytojų komanda.

\section{Literatūra}

1. Moreno CA, Sobreira N, Pugh E, Zhang P, Steel G, Torres FR, et al. Homozygous deletion in MYL9 expands the molecular basis of megacystis-microcolon-intestinal hypoperistalsis syndrome. Eur J Hum Genet 2018;26(5):669-75.

https://doi.org/10.1038/s41431-017-0055-5

2. Nakamura H, O'Donnell AM, Puri P. Consanguinity and its relevance for the incidence of megacystis microcolon intestinal hypoperistalsis syndrome (MMIHS): systematic review. Pediatr Surg Int 2019;35(2):175-80.

https://doi.org/10.1007/s00383-018-4390-6

3. Matera I, Rusmini M, Guo Y, Lerone M, Li J, Zhang J, et al. Variants of the ACTG2 gene correlate with degree of severity and presence of megacystis in chronic intestinal pseudo-obstruction. Eur J Hum Genet 2016;24(8):1211-5.

https://doi.org/10.1038/ejhg.2015.275

4. Milunsky A, Baldwin C, Zhang X, Primack D, Curnow A, Milunsky J. Diagnosis of chronic intestinal pseudo-obstruction and megacystis by sequencing the ACTG2 gene. J Pediatr Gastroenterol Nutr. 2017;65(4):384-7.

https://doi.org/10.1097/MPG.0000000000001608
5. Wang Q, Zhang J, Wang H, Feng Q, Luo F, Xie J. Compound heterozygous variants in MYH11 underlie autosomal recessive megacystis-microcolon-intestinal hypoperistalsis syndrome in a Chinese family. J Hum Genet 2019;64(11):1067-73. https://doi.org/10.1038/s10038-019-0651-z

6. Fatema N, Yaqoubi HNA. Megacystis microcolon intestinal hypoperistalsis syndrome. Pan Afr Med J 2018;31:109. https://doi.org/10.11604/pamj.2018.31.109.16702

7. Halim D, Brosens E, Muller F, Wangler MF, Beaudet AL, Lupski JR, et al. Loss-of-function variants in MYLK cause recessive megacystis microcolon intestinal hypoperistalsis syndrome. Am J Hum Genet 2017;101(1):123-9.

https://doi.org/10.1016/j.ajhg.2017.05.011

8. Hiradfar M, Shojaeian R, Dehghanian P, Hajian S. Megacystis microcolon intestinal hypoperistalsis syndrome. BMJ Case Rep 2013;2013:10.1136/bcr-007524.

https://doi.org/10.1136/bcr-2012-007524

\section{A CASE REPORT OF BERDON SYNDROME (MEGACYSTIS MICROCOLON INTESTINAL HYPOPERISTALSIS SYNDROME)}

A. Čibirkaitė, P. Tekoriutė, E. Bučionytė, R. Rokaitė

Keywords: megacystis-microcolon-intestinal hypoperistalsis syndrome, Berdon syndrome, constipation, functional bowel obstruction.

\section{Summary}

Berdon syndrome (megacystis-microcolon-intestinal hypoperistalsis syndrome (MMIHS)) is a rare, congenital and life-threatening syndrome, which exact prevalence is unknown. This article presents a clinical case of Berdon syndrome. This syndrome presents with recurrent symptoms of dynamic intestinal obstruction and urinary bladder dysfunction manifested by urinary retention without any distal obstruction preventing urine drainage. For our patient this syndrome was confirmed by molecular genetic methods at Keio University, Japan, by detecting a de novo heterozygous pathogenic variant of the ACTG2 gene c.769C > T, pArg257Cys. Berdon syndrome is treated symptomatically with parenteral nutrition and giant bladder catheterization.

Correspondence to: agne.cibirkaite@stud.lsmu.lt

Gauta 2020-10-26 